\title{
The New Geography and the New Imperialism: 1870-1918
}

\section{Brian Hudson}

1972. Antipode 9 (2), 12-9. ${ }^{1}$

The 1870's saw the beginning of geography in its modern form. In Europe and the United States, the modern or "new" geography as it was called, emerged as a distinct academic discipline. Significantly, the subject began to develop in the newly emergent Japan at that time too.

This was the period when, according to Marxist theory, capitalism in those same countries evolved into its highest form, imperialism. Lenin clearly distinguished between the new, or modern, imperialism and territorial acquisitions by powerful nations in earlier periods. In its modern economic sense:

Imperialism is capitalism in that stage of development in which the dominance of monopolies and finance capital has established itself; in which the export of capital has acquired pronounced importance; in which the division of the world among the international trusts has begun; in which the division of all territories of the globe among the great capitalist powers has been completed (Lenin, 1916, 89).

Hobson, to whose work Lenin referred in his analysis, identified the year 1870 "as indicative of the beginning of a conscious policy of Imperialism," adding that, "the movement did not attain its full impetus until the middle of the eighties" (Hobson, 1902, 19).

\footnotetext{
${ }^{1}$ Reprinted with permission from Richard Peet.
} 
Writers on the historical development of geography have referred to the stimulus which colonialism and imperialism gave to geographical study in the late nineteenth century, and it has been shown that geographers and geographical organizations did much to encourage the development of overseas empires (McKay, 1943 passim [throughout]; Freeman, 1961, 19; 26-8 passim). The nineteenth century argument for geography on practical grounds has also been briefly noted (Gilbert, 1971, 200-2; Stoddart 1975, 217-8), but little attention has been given by geographers, at least those in the "West", to the promotion of geography as a tool of imperialism since 1870 . The purpose of this paper is to demonstrate that the study and teaching of the new geography at an advanced level was vigorously promoted at that time largely, if not mainly, to serve the interests of imperialism in its various aspects including territorial acquisition, economic exploitation, militarism and the practice of class and race domination.

Western writers have emphasized the role of geography's "grand old men" in the development of the discipline and in the foundation of national schools of geography during the last three decades of the nineteenth century. Vidal de la Blache in France, Mackinder in Britain, Dalla Vedova in Italy, and Davis in the U[nited] $\mathrm{S}$ [tates] are regarded as the fathers of modern geography in their respective countries. Even in Germany, which had almost monopolized European geography since the mideighteenth century, the establishment of modern geography is largely attributed to von Richthofen and Ratzel (Crone, 1970, 32-6).

While there is no reason to belittle the achievements of these pioneers, the importance of individual geographers in the development of the subject should not be exaggerated. The decline of German geography in the decade after the deaths of Humboldt and Ritter in 1859 clearly shows that even the outstanding contributions of two of its most revered scholars were insufficient to stimulate a sustained advance in the subject. Arnold Guyot and George Perkins Marsh in the U.S. did not result in the foundation of a school of geography there in the mid-nineteenth century (Freeman, 1961, 41-2).

It was only when the evolution of capitalist society had created a greatly increased demand for scientific geography that specialist geographers were sought. This did not happen until the eighteen seventies at which time there were few scholars with any advanced geographical training. Nevertheless, in view of the increasingly recognized need for geographers to serve the new order, university teachers of geography were appointed. They were recruited from the ranks of geology, history and other fields. Richthofen and Davis were geologists by training; Vidal de la Blache and Mackinder were drawn from history; Ratzel, who had studied zoology and geology, was a journalist. It was not the "grand old men" who made the new geography. Rather, it was the new geography as demanded by the new imperialism which made their careers as geographers. 


\section{Geography and Militarism}

Why was there seen to be an urgent need for advanced geographical research and training in the late nineteenth century? It is often remarked that war stimulates interest in geography, and there can be no doubt that the Franco-Prussian War of 187071 had this effect. Chief Justice Charles P. Daly, President of the American Geographical Society 1864-99, observed that this was "a war fought as much by maps as by weapons" and attributed the German victory to "skillful military movements performed by an army thoroughly acquainted with all the geographical features of the country over which it was moved" (Keltie, 1885a, 473-74). From this Daly drew the lesson that the fate of a country could depend on the result of a battle and thus, ultimately, on geographical knowledge. It is worth noting here that the Prussian officers of 1870 included former students of Carl Ritter who had taught at the Military School as well as the University [of] Berlin and who became director of studies for the Corps of Cadets (Mackinder, 1895, 37; James, 1973, 166, 217).

The Prussian victory over France in 1871 no doubt further stimulated geographical study in Germany which had long held the lead in this field. Military considerations probably influenced the Prussian government in its decision of 1874 to establish chairs of geography at each of that state's universities (James, 1972, 217). When in 1884 John Keltie made a survey of geographical teaching in higher institutions of learning on the continent he found that in Germany great importance was attached to geography in the training of military officers. The subject was taught not only as it directly related to the science of war. As the instructions on the scope and methods of study at the Kriegs-Akademie, Berlin indicated, geography was also emphasized for its wider educational value in explaining [human]-land relationships and the development of states, and in imbuing the student officers with a sense of mission as bearers of European civilization (Keltie, 1885a, 549).

The vanquished as well as the victors were quick to appreciate the strategic importance of geographical knowledge, and in his report of 1885 Keltie observed, "In no country has the progress of geographical education been greater than in France during the last fourteen years" (Keltie, 1885a, 449). This was particularly apparent at the two great military schools, St. Cyr and the staff College in Paris where "geography in its widest sense was the chief subject of education" (Keltie, 1885b, 501).

Britain, perhaps because of [its] insularity and perhaps because [it] had the advantage of a comfortable lead at the start of the renewed race for empire, lagged behind the continent in the teaching of geography. Colonel Sir Thomas H. Holdich, when vice-president of the Royal Geographical Society, asserted that increased awareness of the need for scientific geographical education in Britain stemmed largely from "the practical consideration that we were being left very far behind in the field" (Holdich, 1916, 181). This could put the country at a serious military disadvantage as operations in the Afghan and Boer Wars had amply demonstrated (Goldie, 1907, 8; Holdich, 1916, 180; Mason, 1930, 210). Holdich, who regarded war as "the first and greatest civilising agent", fully understood the army's vital role in imperialism 
(Holdich, 1916, 15), and no one more than he appreciated the importance of scientific geography for military purposes (Holdich, 1899, 465-6, 477; 1916, 180-1).

In Britain officers of the armed forces, acting through the Royal Geographical Society, were amongst the most energetic champions of advanced geographical education. The strength of military and naval influence in the society in the late nineteenth and early twentieth centuries is indicated by the fact that during that period normally between a third and a half of the thirty four council members were officers of the army and navy. Through the society these men helped to establish the teaching of geography in British universities. The Royal Geographical Society delegation to Oxford, which made arrangements for the first British school of geography there, included representatives of both the army and navy (Holdich, 1899, 466). Holdich, himself, was amongst those who gave advice and assisted in the preliminary negotiations for the Oxford School of Geography which was established in 1899 (Markham, 1899, 480).

Oxford had had a Reader in geography, Mackinder, since 1887 and Cambridge, a lectureship in geography since 1888 , but even this modest advance was much later than the establishment of chairs of geography on the continent. By this date there were no fewer than twelve chairs of geography in Germany, alone, and universities in France, Switzerland, the Netherlands and Italy had university teachers of geography with full professorial rank (Keltie, 1885a, 476, 486, 519-20). France then had seven state-endowed chairs of geography, of which those at Caen, Bordeaux and Lyons had been founded within six years after the end of the Franco-Prussian War (Reltie, 1885a, $501,520)$.

\section{Geography and the Growth of Empires}

The rapid development of advanced geographical education in Europe, notably France, must be largely attributed to the renewed interest among the European powers in overseas colonial empire. Germany actually encouraged both France and Italy in their colonial ambitions, partly to create discord between these two rival powers. Bismark's interest in the acquisition of a German colonial empire did not develop until later, and this was mainly for diplomatic reasons (Mansergh, 1949, 89).

The balance of power in Europe left France with the alternatives of a policy of resignation or enlarging [its] empire. It was the latter course which [it] adopted with the active encouragement of the French geographical societies.

It could be said that just as French geographers, through these societies, promoted colonial expansion, so did the growth of the French Empire stimulate the development of geography in France (de Martonne, 1924, 3). Courses in colonial geography became prominent in French universities, and a chair of colonial geography was established in Paris in 1892 (Church, 1957, 70-1). 
Although geography did not find a place in Belgian universities until the last decade of the nineteenth century, the value of geographers in deliberations on the extension of European interests overseas had been recognized by the King of the Belgians in 1876. In that year Leopold II summoned to Brussels geographers and explorers from Britain, France, Germany, Austria, Hungary, Italy, and Russia to discuss the "opening up" of central Africa. The eventual outcome was not international co-operation in that vast region, but the carving out of the Congo Free State as King Leopold's personal domain. The subsequent partition of most of Africa at the Berlin Conference of 1884-5 was done without the benefit of adequate geographical knowledge with absurd results. In consequence various expensive arbitrations and commissions became necessary to settle the boundary disputes (Herbertson, 1910, 469; Holdich, 1916, 54).

Britain's Holdich, an experienced military surveyor who became superintendent of Frontier Surveys in 1892, was acutely aware of the usefulness of geographical knowledge in the demarcation of satisfactory boundaries for the expanding European empires. He knew, too, that countries with superior geographic knowledge and skills were at a great advantage in negotiations over national spheres of influence and territorial partition:

It is, perhaps, in those international negotiations and agreements which concern the political status of great countries, and determine their boundaries and the respective limits of their responsibilities, that the danger of inaccurate geographical knowledge is greatest, and the results of it are the most disastrous. Truly, this period in our history has been well defined as the boundary-making era. Whether we turn to Europe, Asia, Africa, or America, such an endless vista of political geography arises before us, such a vast area of land and sea to be explored and developed; such a vision of great burdens for the white man to take up in far-off regions, dim and indefinite as yet; that it can surely be only by the grace of Providence that we shall finally emerge from the struggle to rearrange the world's partitioning, without some deadly contest with others whose interests in these new arrangements are hardly less than our own. And I may, perhaps, be permitted to say, that just as the Providence of battles usually favors the biggest battalions, so it is likely that the widest geographical knowledge will prove the best safeguard against misunderstandings, and will at once dispose of such false estimates of the value of portions of the world's surface here and there as have occasionally brought England perilously close to the dividing line between peace and war. By geographical knowledge I do not mean simply that knowledge of the Earth's surface which we gain by surveying it. I mean also a knowledge of those ordinary laws of nature which decide the configuration of mountains and the flow of rivers, where certain influences must inevitably lead to certain conditions (Holdich, 1899, 466-7). 
It was practical reasons such as this which led to the establishment of geographical education at British universities between 1887 when geography gained a foothold at Oxford, and 1917 when the country's first honours school was founded at Liverpool.

\section{Economic Exploitation of Overseas Territories}

The resources of a world now undergoing complete partition were regarded in Europe as "the gifts the gods provide as the white man's opportunity for acquiring wealth and power" (Holdich, 1916, 243). Naturally, the colonial powers were anxious to discover the economic potential of the territories which they had acquired or whose annexation they were considering. Here again geographical knowledge was recognized as an invaluable tool of imperialism. Clements Markham observed in 1893, "The time for desultory exploring expeditions is past" (Markham, 1893, 487). A sound scientific approach involving appropriately trained workers in the field has now required. Geographers could not only provide useful information about a country's resources but were also able to advise how these might best be exploited.

Richthofen, for example, was sent by his government on trade and resource mapping missions in Asia and America. He became an influential adviser to the Prussian Government and a member of the Kolonialrat [Colonial Advisory]. As a result of his work in China he appreciated the importance of the Shantung Peninsula with its coalfield and favourable trading position, and he was largely responsible for Germany's acquisition of Kiaochow (Crone, 1970, 33).

The "Geographical Factor in Imperial Problems" was stressed by Herbertson in his presidential address to Section E of the 1910 British Association meeting in Sheffield (Herbertson, 1910, 447-8). Here he advocated the use of university trained geographers in mapping the economic value of different parts of the world and went further to suggest that geographical laws should be applied to forecast future economic development. Herbertson foresaw the establishment of Geographical Statistical Departments in various countries to undertake research of this kind. This he claimed was greatly needed in Britain and its Empire for which an Imperial Intelligence Department could be developed. The universities were expected to provide the trained men for this research, and the necessity for geographical education at university level was thus further emphasized (Herbertson, 1910, 478).

The type of geography which was being taught in at least some British universities reflected the nature of the demand. Geography was seen largely as a practical rather than a purely academic subject. In 1899 Mackinder said, "It is just because of that practical side of university work in this country that I value most the geographical teaching which it is now proposed to extend from the comparatively humble basis of the past few years" (Mackinder, 1899, 479). 
By this time geography was being taught at the universities of Oxford, Cambridge, and London and in some of the universities and colleges which had been founded not long before in the great commercial and industrial cities of England. Classes in geography were being held at University College, Liverpool and Owen's College, Manchester, largely as an adjunct to commercial studies. Manchester was also the first British city outside London to have its own geographical society. In the same year, 1884, the Scottish Geographical Society was founded in Edinburgh, and this was followed by societies in Newcastle-on-Tyne (1887) and Liverpool (1892).

In an address to the Manchester Geographical Society in 1884 the imperialist attitude to geography and world trade was vividly expressed by H. M. Stanley who described geography as "a science which may best be called the admonitor to commerce" (Stanley, 1885, 24). The celebrated explorer, speaking in Winchester's Free Trade Hall, said that to those who possess geographical knowledge," the configurations on the world chart appear as clearly defined as though they were the outlines of a man's real estate - the world is only a huge breeding farm, and the various parts round about the shores are like so many stalls at a market-place - and the people therein are only so many vendors and buyers" (Stanley, 1885, 8).

Stanley noted the intimate link between geography and the growth of the British Empire, and exhorted his listeners to promote geographical education among young people to encourage them to embark on overseas enterprises:

And whereas you owe so much to geographical knowledge you must cherish that knowledge, and go on acquiring it, you must teach it to your youths, that when they arrive at manhood each may know that beyond these islands there lie vast regions where they also may carve out fortunes as their forefathers did in olden time. You must extend it among the mature men, that by the exhibition of it they may be led to reflect, if in some little known part of this world there may not lie as rich markets as any now so earnestly competed for (Stanley, 1884, 13-4).

To the businessmen in his audience Stanley offered the prospect of profitable markets in Africa which could be opened up by railway projects "which any half-adozen rich capitalists of Manchester could cause to be made" (Stanley, 1885, 16).

It was the merchants of the city who were mainly responsible for the establishment of the Manchester Geographical Society. Significantly, when its formation was first proposed the name suggested for it was The Society of Commercial Geography, (Manchester Geographical Society, 1885a, 64-6). The President of the Manchester Chamber of Commerce, J. F. Button, in his inaugural address as President of the Manchester Geographical Society, made it clear why at last British merchants were beginning to promote geographical education when he said, "The encouragement of such study is erecting one of the mainstays of commerce" (Hutton, 1885, 2). 
The Manchester Geographical Society was established to promote the study of all branches of geography "especially in relation to commerce and civilization," (Manchester Geographical Society, 1885b, 3) and it was convenient to regard conquest and the economic exploitation of overseas territories as the bringer of peace, Christianity and advancement to warring pagan savages who were unable to conduct their own affairs satisfactorily. Typical of the views expressed at the time is that of $\mathrm{H}$. H. Johnston who in conclusion to a talk to the Manchester Geographical Society on 'The Commercial Prospects of Tropical Africa', urged upon his audience "the conviction that the progress of religion, the establishment of peace, and the civilization of mankind are intimately bound up with the commercial prospects of Tropical Africa" (Johnston, 1885, 196).

\section{Geography, Race and Class}

Racism was common in European geographical circles and this was never more strongly expressed than when overseas white domination and settlement were being discussed. Colonel Sir Thomas H. Holdich, then Vice- President of the Royal Geographical Society asserted: "The right of the white man to fill the earth and subdue it has always been unquestioned, because it is based on the principle that his dominance and lordship tend to the betterment of the world and straightens out the highways for peace and the blessings of civilization to follow" (Holdich, 1916, 61). It is ironic that these words were written while European nations were locked in the most devastating and bloody war that had been known to [humanity].

One of the important concerns of European and American geographers at that time was the influence of the physical environment on culture and civilization. Indeed, H. R. Mill suggested that, "The ultimate problem of geography may perhaps be taken as the determination of the influence of the surface forms of the Earth on the mental processes of its inhabitants" (Mill, 1905, 15). This period saw the publication of three of the classics of deterministic geography, Friedrich Ratzel's Anthropogeographie (1882-91), Ellen Churchill Semple's Influences of Geographic Environment (1911) and Ellsworth Huntington's Civilization and Climate (1915). The latter was an attempt to give scientific support to the widely-held belief that high levels of civilization could only be achieved in regions of stimulating climate and that monotonous tropical heat had a stunting effect on human development. Holdich, like many of his contemporaries held the view that, "Environment shaped national character" (Holdich, 1916, 13) and believed that a "fierce struggle has commenced for the survival of the fittest, which we must regard as the heritage of the world's overgrowth of population" (Holdich, 1916, 245).

Climate was regarded as perhaps the main single determinant which gave Europeans their supposed superiority in the struggle for survival. The effects of climate were considered to be more powerful than racial inheritance. Referring to proposals for European settlement in Tropical Africa, John Scott Keltie expressed the fear "that the 
ultimate result would be a race deprived of all those characteristics which have made Europe what it is" (Keltie, 1897, 315). Keltie noted that, "Even in such favourable situations as Blantyre, a lofty region on the south of Lake Nyasa, children cannot be reared beyond a certain age; they must be sent home to England, otherwise they will degenerate physically and morally" (Keltie, 1897, 315).

The apparent effects on the indigenous population of continued exposure to these debilitating influences for countless generations was clearly recognized by the European imperialists. Explorers in the Lake Nyasa region reported that, "The average black in these parts is incapable of concentrating his attention upon any one thing for more than a few consecutive minutes; his train of continued thought is remarkable for its brevity; his memory concerning those things a white man could have him remember is that of a little child; his faculties are hard tried before they can fully grasp the subtle difference between 'right turn' and 'left turn"' (Money and Smith, 1897, 147).

The stereotype of the stupid, lazy, filthy, degenerate and cruel native was reported from all over the tropical world by white explorers, missionaries, traders, settlers and others. In southern Nigeria, for example, a military explorer observed that, "The typical characteristics of the various tribes in these parts are, in the main, those which are common to all savage peoples" (E. A. Steel, 1908, 14). Enlarging on this the British officer reported that, "The work of cultivating the ground just sufficient for their needs is done by the women and children, while the men do nothing but eat and drink and sleep and enjoy themselves. They have no physique, no intelligence; their habits are of the dirtiest description, and nothing gives them so much pleasure as the sacrifice of human blood" (E. A. Steel, 1908, 16). The officer recorded that some of the native tribes were superior to the majority whom were considered the most despicable savages in the world" (E. A. Steel, 1908, 16). He wrote, "There are some exceptions and the reason for these can be attributed to the influence of geographical conditions or their different modes of life. The Oka people, bordering on the Onicha district, and the Elugus to the east, represent also fine specimens of natives, and this may in way be due to the comparatively hilly nature of their country - Bende particularly so" (E. A. Steel, 1908, 14-5).

Similarly deterministic views were expressed by Holdich with particular reference to India: "The indolent sun-loving people of Southern latitudes have everywhere proved more easy to dominate than those who have been nurtured in a colder atmosphere. We can rule the millions of Hindu and Mohamadan agriculturalists of the India plains with far less violent effort than the thousands in the hills and uplands of the frontier" (Holdich, 1916, 13-4).

Clearly in Europe and North America it was a widely held view that the character and achievements of the peoples of the world were largely determined by physical or "geographical" factors, especially climate. The supposed superiority of European peoples and their descendants in suitable environments overseas had been determined by Nature which had also condemned less fortunate peoples to inferior 
status. The white man, therefore, saw himself as the natural inheritor of the world's wealth and master of its peoples.

Thus environmental or geographic determinism was used as an ideological buttress for imperialism and racism. This is well illustrated by remarks made by Sir George Taubman Goldie at a meeting of the Royal Geographical Society held in commemoration of Queen Victoria's reign: "Now, looking only at British America, Australasia and Africa, because British India is outside my province tonight, these fall roughly into two sections, one of which is peopled mainly by white races capable of self-government, while the other is peopled by coloured races, which (when unprotected) fall prey to cruel tyranny and inhuman fetish practices, or are devastated by unceasing inter-tribal war, or are swept away by the incursions of slave-raiding hordes" (Goldie, 1901, 240). Goldie's distinguished audience no doubt armed to his patriotic sentiments when he said, "It is impossible for an Englishman to behold our distant colonies without a high pride and satisfaction. To hoist the British flag seems to draw with it, as a certain consequence, wealth, prosperity, and civilization" (Goldie, 1901, 235).

Britain and other white imperialist nations were anxious to provide the "protection" which the "coloured races" obviously required. It was indeed a happy situation that made the aggressive pursuit of wealth and power a moral obligation.

Among the most urgent geographic problems of the period was the search for those parts of the world which were seen as suitable "dumping grounds" for Europe's excess population (Holdich, 1916, 227). There were many who, like Holdich, regarded as "paramount" the "problem of the expansion of the white races through those regions of the world suitable for its continuance, a problem which grows in weight and importance from year to year, and which must, in a not very remote future, find a partial solution in the extermination of many of the dark-skinned races which now reveal to investigators a practical epitome of the development of humanity from its earliest beginnings" (Holdich, 1916, 245). Holdich foresaw the problem of possible future military resistance by the "coloured races" to white expansion and he accepted that "the solution of it will inevitably lie with the sword" (Holdich, 1916, 61).

Some may feel that one ought not to attach great weight to extreme statements of men like Holdich who might be regarded as exceptional and unrepresentative of the geographical community. It should be recognized, however, that Holdich was for twenty-five years a member of the Royal Geographical Society Council for which he was a prominent spokesman. In 1917, the year after the publication of his Political Frontiers and Boundary Making, from which some of his most extreme statements are quoted in this paper, he was elected President of the Royal Geographical Society. Holdich clearly met with the full approval of many of his geographical colleagues.

Although not professed by all geographers, determinism was seized upon as a weapon of imperialism by men such as Holdich (Holdich, 16, 13-4), and not surprisingly, a strong sense of class superiority flourished alongside these racial 
attitudes, at least in British geographical circles. It was mainly the excess numbers of British "labouring class" people for whom "dumping grounds" were being sought in Africa and elsewhere (Holdich, 1916, 254). Unemployment and other social problems were rife in Europe, and even in England there was fear of revolution. Massive emigration was seen as one possible solution. Cecil Rhodes is reported to have made the following remarks in 1895 :

I was in the East End of London yesterday and attended a meeting of the unemployed. I listened to the wild speeches, which were just a cry for 'bread', 'bread', 'bread', and on my way home I pondered over the scene and I became more than ever convinced of the importance of imperialism. My cherished idea is a solution for the social problem, i.e., in order to save the United Kingdom from a bloody civil war, we colonial statesmen must acquire new lands to settle the surplus population, to provide new markets for the goods produced by them in the factories and mines. The Empire, as I have always said, is a bread and butter question. If you want to avoid civil war, you must become imperialists (Lenin, 1916, 76).

Apart from the working class emigrants there were the administrators, planters and others of higher socio-economic status who would go overseas, but who would in most cases return to their home country at the end of their tours of duty or when their fortunes had been made. While for the working class the science of geography was investigating the question of potential dumping grounds, for "the most valuable classes of English gentlemen" geography was being promoted as an important part of university education which would help to equip them for their roles in running the business of the Empire (Rawlinson, 1871, 517-8).

\section{Conclusion}

It would not be entirely true to say that the promotion of geographical education was for practical imperialist purposes alone. Many of its advocates had genuine scholarly interest in the subject. Among these were scholars in other disciplines who saw the need for geography as it related to their own fields. For example, the zoologist, Professor A. Newton of Cambridge, saw the need for geography because his students, being ignorant of the subject, were unable to understand his lectures on the geographical distribution of animals (Keltie, 1885a, 545). Historians and classical scholars, too, were among those who advocated the teaching of geography at the universities, J. L. Myers, Professor of Greek at Liverpool, later Professor of Ancient History at Oxford, being one of the most influential (Mason, 1954, 541-2; R. W. Steel, 1967).

Nevertheless, in Britain, as on the continent and in the U.S., it was not so much the demands of scholarship "that forced the conservative hand of our educational 
administration, and led to the formation of geographical schools throughout the length of the country," but the realization that, for imperialist countries, "geography was a science that had to be reckoned with, and which it paid pre-eminently to study" (Holdich, 1916, 181).

\section{References}

Church, H. H. 1957. The French school of geography. In, G. Taylor (ed.) Geography in the 20th Century. London: Methuen, pp. 70-90.

Crone, G. R. 1970. Modern Geographers. London, Royal Geographical Society.

de Martonne, E. 1924. Geography in France. New York: American Geographical Society.

Freeman, T. W. 1961. A Hundred Years of Geography. Chicago: Aldine Publishing Co.

Gilbert, E. W. 1971. The RGS and geographical education in 1871. Geographical Journal 137(2), 200-2.

Goldie, G. T. 1907. Geographical ideals. Geographical Journal 29(1), 1-14.

Goldie, G. T. 1901. Progress of exploration and the spread and consolidation of the Empire in America, Australia and Africa. Geographical Journal 17(3), 231-40.

Herbertson, A. J. 1910. Geography and some of its present needs. Geographical Journal 36 (4), 468-79.

Hobson, J. A. 1902. Imperialism - A Study. $3^{\text {rd }}$ ed. (1938) London: George Allen \& Unwin Ltd.

Holdich, T. H. 1916. Political Frontiers and Boundary Making. London: Macmillan \& Co., Ltd.

Holdich, T. H. 1899. The use of practical geography illustrated by recent frontier operations. Geographical Journal 13(5), 465-80.

Hutton, J. F. 1885. Inaugural address to the Society. Journal of the Manchester Geographical Society 1(1-3), 1-6.

James, P. E. 1972. All Possible Worlds: A History of Geographical Ideas. Indianapolis and New York: Odyssey Press. 
Johnston, H. H. 1885. The commercial prospects of tropical Africa. Journal of the Manchester Geographical Society 1(7-9), 179-96.

Keltie, J. S. 1897. Some geographical problems. Geographical Journal 10 (3), 308-23.

Keltie, J. S. 1885a. Geographical education. Report to the Council of Royal Geographical Society: Supplementary Papers RGS 1(4), 439-595.

Keltie, J. S. 1885b. Geographical education. Scottish Geographical Magazine 1(10), 497-505.

Lenin, V. I. 1916. Imperialism: The High-Stage of Capitalism. New revised translation. 1938. New York: International Publishers Co., Inc.

Mackinder, H. J. 1899. Discussion of paper by Holdich. Geographical Journal 13(5), $479-80$.

Mackinder, H. J. 1895. Modern Geography, German and English. Geographical Journal 6(4), 367-79.

Manchester Geographical Society. 1885a. A short note on the origin of the Society. Journal of the Manchester Geographical Society 1(1-3), 64-6.

Manchester Geographical Society. 1885b. Rules of the Manchester Geographical Society, 1. Objects and work. Journal of the Manchester Geographical Society $1(10-12), 3$.

Mansergh, N. 1949. The Coming of the First World War. A Study in the European Balance. London: Longmans, Green and Co., Ltd.

Markham, C. 1899. Speech Proposing Vote of Thanks to Holdich, op. cit. [i.e. from the work cited]

Markham, C. 1893. The present standpoint of geography. Geographical Journal 2(6), 481-505.

Mason, K. 1954. John Linton Myers, 1869-1954, obituary. Geographical Journal 120(4), 541-2.

Mason, K. 1930. Colonel Sir Thomas Hungerford Holdich, obituary. Geographical Journal 75(3), 209-15.

McKay, D. V. 1943. Colonialism in the French geographical movement 1871-1881. Geographical Review 33(2), 214-32.

Mill, H. R. 1905. The present problems of geography. Geographical Journal 25(1), 117. 
Money, R. I. \& S. K. Smith. 1897. Explorations in the country west of Lake Nyasa. Geographical Journal 10(2), 146-72.

Rawlinson, H. C. 1871. Extract from a letter sent to the Vice-Chancellor of the Universities of Oxford and Cambridge from the President and Council of the Royal Geographical Society. In, J. S. Keltie (ed.), Geographical education. Report to the Council of Royal Geographical Society: Supplementary Papers RGS 1(4), 517-18.

Stanley, H. M. 1885. Central Africa and the Congo Basin; or, the importance of the scientific study of geography. Journal of the Manchester Geographical Society $1(1-3), 6-25$.

Steel, E. A. 1908. Explorations in Southern Nigeria. Geographical Journal 32(1), 125.

Steel, R. W. 1967. Geography at the University of Liverpool. In, R. W. Steel and R. Lawton (eds.), Liverpool Essays in Geography. London: Longmans, pp. 1-23.

Stoddart, D. R. 1975. The RGS and the Foundation of Geography at Cambridge. Geographical Journal 141(2), 216-39. 